\title{
Cerasibacillus quisquiliarum gen. nov., sp. nov., isolated from a semi-continuous decomposing system of kitchen refuse
}

Correspondence

Kohei Nakamura

k-nakamura@mbj.nifty.com

\author{
Kohei Nakamura, ${ }^{1}$ Shin Haruta, ${ }^{1}$ Shintaro Ueno, ${ }^{1}$ Masaharu Ishii, ${ }^{1}$ \\ Akira Yokota ${ }^{2}$ and Yasuo Igarashi ${ }^{1}$
}

\author{
Department of Biotechnology, Graduate School of Agricultural and Life Sciences ${ }^{1}$ and \\ Laboratory of Bioresources, Institute of Molecular and Cellular Biosciences ${ }^{2}$, The University \\ of Tokyo, Yayoi 1-1-1, Bunkyo-ku, Tokyo 113-8657, Japan
}

\begin{abstract}
A moderately thermophilic and alkaliphilic bacillus, which had been reported and designated BLx (Haruta et al., 2002), was isolated from a semi-continuous decomposing system of kitchen refuse. Cells of strain $\mathrm{BLx}^{\top}$ were strictly aerobic, rod-shaped, motile and spore forming. The optimum temperature and $\mathrm{pH}$ for growth were approximately $50{ }^{\circ} \mathrm{C}$ and $\mathrm{pH} 8-9$. Strain $\mathrm{BLx}{ }^{\top}$ was able to grow at $\mathrm{NaCl}$ concentrations from 0.5 to $7.5 \%$, with optimum growth at $0.5 \% \mathrm{NaCl}$. The predominant menaquinone was MK-7, and the major fatty acid was iso- $\mathrm{C}_{15: 0}$. Phylogenetic analysis showed that strain $\mathrm{BLx}^{\top}$ was positioned in an independent lineage within the cluster that includes the genera Virgibacillus and Lentibacillus in Bacillus rRNA group 1. Strain BLx ${ }^{\top}$ exhibited 16 S rDNA similarity of $92 \cdot 8-94 \cdot 8 \%$ to Virgibacillus species and $92 \cdot 3 \%$ to Lentibacillus salicampi. Phenotypic, chemotaxonomic and phylogenetic analyses supported the classification of strain $\mathrm{BLx}^{\top}$ in a novel genus and species. Cerasibacillus quisquiliarum gen. nov., sp. nov. is proposed on the basis of phenotypic, chemotaxonomic and phylogenetic data. The type strain is $B L x^{\top}\left(D S M 15825^{\top}=I A M 15044^{\top}=K C T C 3815^{\top}\right)$.
\end{abstract}

Biological treatment is an efficient way to manipulate solid organic wastes that are produced in agriculture, industry and in residential areas. Composting by a microbial community is one solution for waste treatment. During the composting process, the temperature of the compost often reaches $80{ }^{\circ} \mathrm{C}$ because of the heat produced by the microbial community from the decomposition of organic matter (Finstein et al., 1975). Studies of microbial communities during the composting process have been performed by several researchers using cultivation-based methods (Beffa et al., 1996; Fujio \& Kume, 1991; Pedro et al., 2003; Nakasaki et al., 1985; Ryckeboer et al., 2003; Strom, 1985a, b). Various species of bacteria have been isolated from composting processes, and many of the isolates are thermophilic (or moderately thermophilic) and belong to the family Bacillaceae. They are thought to play important roles in the composting process.

We have been analysing the microbial community present during the decomposition of kitchen refuse in a laboratoryscale semi-continuous decomposing system (Haruta et al.,

\footnotetext{
Abbreviations: DAP, diaminopimelic acid; DGGE, denaturing gradient gel electrophoresis; FISH, fluorescence in situ hybridization.

The GenBank/EMBL/DDBJ accession number for the 16S rDNA sequence of strain BLx ${ }^{\top}$ is $A B 107894$.
}

2002). As the decomposition proceeded under conditions of high temperature (up to nearly $55^{\circ} \mathrm{C}$ ) and alkalinity ( $\mathrm{pH}$ 8-9), a Bacillus licheniformis-like band was detected reproducibly under multiple operations using denaturing gradient gel electrophoresis (DGGE). The strain that was represented by the band was designated BLx. Fluorescence in situ hybridization (FISH) analysis reproducibly revealed that BLx was present as the dominant strain in the community. Furthermore, sequences with high similarity to that of strain BLx have been reported from other organic substance degradation processes: AB028110 (Kurisu et al., 2002) and AB029411(Ishii et al., 2000). Strain BLx is thought to play an important role in the degradation of organic materials because it appears to exist in decomposing systems under conditions of high temperature and alkalinity. In this paper, we report the isolation and characterisation of strain BLx from a kitchen refuse decomposing system. Based on our results, we propose Cerasibacillus quisquiliarum gen. nov., sp. nov., for strain $\mathrm{BLx}^{\mathrm{T}}$.

Strain $\mathrm{BLx}^{\mathrm{T}}$ was isolated from a decomposed refuse sample from a decomposing system that was operated as previously described (Haruta et al., 2002). Samples $(10 \mathrm{~g})$ were collected $12 \mathrm{~h}$ after addition of standard kitchen garbage and homogenized in $60 \mathrm{ml}$ saline $(0 \cdot 85 \%$ $\mathrm{NaCl}$ ) with a POLYTRON homogenizer (Kinematica) at 
15000 r.p.m. for $5 \mathrm{~min}$. The homogenized sample was serially diluted with saline and spread on tryptic soy agar plates (TSA; tryptic soy broth, Difco, containing $1.5 \%$, w/v, agar). Plates were incubated at 37 or $50{ }^{\circ} \mathrm{C}$. Colonies with different morphologies were isolated and purified at least three times. Isolates were then cultivated in tryptic soy broth (TSB; Difco). Cells were harvested by centrifugation, washed twice with saline and stored at $-20^{\circ} \mathrm{C}$ for DNA preparation. Isolates that grew on the plates were stored at $4{ }^{\circ} \mathrm{C}$ for further cultivation.

Strain $\mathrm{BLx}^{\mathrm{T}}$ was screened by specific PCR from the isolates. Frozen cell pellets were suspended in sterilized distilled water, boiled for $5 \mathrm{~min}$, and cooled immediately on ice. Extracted genomic DNA was recovered by centrifugation and used as a PCR template. Almost complete 16S rDNA sequences were amplified from these extracted genomic DNAs using the universal primers $F\left(5^{\prime}\right.$-AGAGTTTGATCCTGGCTCAG-3'; Escherichia coli positions 8-27) and R (5'-ACGGCTACCTTGTTACGACT-3'; E. coli positions 1512-1492) (Devereux et al., 1995). Amplified products were applied to specific PCR, which was performed using the $\mathrm{BLx}^{\mathrm{T}}$-specific primer, BL3R (5'-ACCGRCCTATTCGAACGGTAC- $3^{\prime}$ ), whose sequence corresponds to a $\mathrm{BLx}^{\mathrm{T}}$ specific FISH probe, BL3 (Haruta et al., 2002), and the primer F. The composition of $20 \mu \mathrm{l}$ of PCR cocktail was as follows: PCR Gold buffer (Perkin-Elmer Biosystems), $1.5 \mathrm{mM} \mathrm{MgCl}_{2}, 0.2 \mathrm{mM}$ dNTPs, $2.5 \mu \mathrm{M}$ primer $\mathrm{F}, 2.5 \mu \mathrm{M}$ BL3R, 0.5 U AmpliTaq Gold (Perkin-Elmer Biosystems) and $1 \mu \mathrm{l}$ template (16S rDNA fragment). The conditions for specific PCR were as follows: $95^{\circ} \mathrm{C}$ for $5 \mathrm{~min}, 30$ cycles at $93^{\circ} \mathrm{C}$ for $30 \mathrm{~s}$ and $72{ }^{\circ} \mathrm{C}$ for $30 \mathrm{~s}, 94^{\circ} \mathrm{C}$ for $1 \mathrm{~min}$, and finally $72^{\circ} \mathrm{C}$ for $5 \mathrm{~min}$. PCR products were confirmed by $2.0 \%(\mathrm{w} / \mathrm{v})$ agarose gel electrophoresis. Specific PCR products were identified from two isolates that were obtained from a sample whose temperature and $\mathrm{pH}$ were $46^{\circ} \mathrm{C}$ and $8 \cdot 6$, respectively. $16 \mathrm{~S} \mathrm{rDNA}$ sequence analysis was performed with one of the isolates. The sequence of variable region 3 of the $16 \mathrm{~S}$ rDNA of the isolate was identical to that of the DGGE bands of the B. licheniformis-like strain X68416. Based on this information, the isolate was identified as strain $\mathrm{BLx}^{\mathrm{T}}$.

Strain $\mathrm{BLx}^{\mathrm{T}}$ was maintained in TSB or on TSA ( $\mathrm{pH} 8 \cdot 5$, adjusted with $\mathrm{NaOH}$ ). Cell wall and menaquinone composition and DNA were examined with cells cultured in these media. Marine agar (MA; Difco) was used for fatty acid methyl ester (FAME) analysis.

Colony morphology was observed after 4 days incubation on TSA at $37^{\circ} \mathrm{C}$. For sporulation, $\mathrm{BLx}^{\mathrm{T}}$ was cultivated for 12 days at $37^{\circ} \mathrm{C}$ on TSA containing the following trace elements: $\mathrm{MgSO}_{4}(1 \mathrm{mM}), \mathrm{Ca}\left(\mathrm{NO}_{3}\right)_{2}(1 \mathrm{mM}), \mathrm{MnCl}_{2}$ $(10 \mu \mathrm{M})$ and $\mathrm{FeSO}_{4}(1 \mu \mathrm{M})$. One loopful of colony material was swabbed onto a glass slide. Dried cells were observed with an Olympus BX60 phase contrast microscope. Gram reaction, oxidase production and catalase production were determined by conventional procedures. For anaerobic growth, BLx ${ }^{\mathrm{T}}$ was cultivated on TSA in an AnaeroPack
(Mitsubishi Gas Chemical) pouch bag with an oxygen absorber. The API $50 \mathrm{CHB}$ system (bioMérieux) was employed, following the manufacturer's instructions, to identify the following biochemical properties: acid production from carbohydrates, hydrolysis of aesculin, gelatin, starch and urea, $\mathrm{H}_{2} \mathrm{~S}$ production and nitrate reduction. Casein hydrolysis was detected with TSA containing $5 \%$ skimmed milk. BLx ${ }^{\mathrm{T}}$ was cultivated at $50{ }^{\circ} \mathrm{C}$ in TSB containing various concentrations of $\mathrm{NaCl}$ and optical density at $660 \mathrm{~nm}$ was measured during incubation. BLx ${ }^{\mathrm{T}}$ was cultivated in TSB at a range of temperatures $\left(26 \cdot 5-55^{\circ} \mathrm{C}\right)$.

Genomic DNA was extracted from cells according to the procedure of Zhu et al. (1993). The isomer type of diaminopimelic acid (DAP) was determined by the method described by Schleifer (1985). Menaquinone was extracted from freeze-dried cells and analysed by the method of Collins \& Jones (1982). For the analysis of fatty acid composition, one loopful of cell mass grown on MA for 7 days at $30{ }^{\circ} \mathrm{C}$ was obtained and FAMEs were prepared and identified following the Microbial Identification System (MIDI) instructions. The G $+\mathrm{C}$ content was determined by reverse-phase HPLC, as described by Tamaoka \& Komagata (1984).

The almost complete $16 \mathrm{~S}$ rDNA was amplified by PCR with the two universal primers, $\mathrm{F}$ and $\mathrm{R}$, mentioned above. The PCR product was subjected to agarose gel electrophoresis and purified with a QIAEX gel extraction kit (QIAGEN). The purified 16S rDNA was sequenced directly using the ABI PRISM BigDye Terminator Cycle Sequencing Ready Reaction kit and an ABI PRISM model 377 genetic analyser (Perkin-Elmer). The sequences obtained were aligned using the CLUSTAL X program (version 1.81; Thompson et al., 1997). The multiple sequence alignment was then corrected manually when necessary. A phylogenetic tree was constructed from evolutionary distance data (Kimura, 1980) by applying the algorithm of the neighbour-joining method (Saitou \& Nei, 1987) using MEGA version 2.1 (Kumar et al., 2001). To evaluate the robustness of the inferred tree, the bootstrap resampling method of Felsenstein (1985) was used with 1000 replicates.

A number of strains belonging to the family Bacillaceae have been isolated from decomposition processes of solid organic waste (Fujio \& Kume, 1991; Ryckeboer et al., 2003; Strom, 1985b). Most of the strains are thermophilic and are thought to play important roles during the decomposition process. Molecular biological analyses have been used to observe the microbial community during these processes (Dees \& Ghiorse, 2001; Ishii et al., 2000; Peters et al., 2000). Compared with conventional cultivation/isolation-based techniques, molecular biological techniques can indicate the existence of uncultured or viable but non-culturable (VBNC) microorganisms. However, these techniques are not specific for live cells, since DNA is extracted not only from living cells but also from dead cells in environmental samples. In addition, biases may have occurred because of 
differences in DNA-extraction efficiencies in different samples or during PCR (LaMontagne et al., 2002; Watanabe et al., 2001). These disadvantages should be considered when applying molecular biological techniques.

Strain $\mathrm{BLx}^{\mathrm{T}}$ has been identified in the decomposition of kitchen refuse using the molecular biological technique, DGGE analysis (Haruta et al., 2002). B. licheniformis was its closest relative, based on the sequence of the DGGE bands. Moreover, FISH analysis indicated that $\mathrm{BLx}^{\mathrm{T}}$ was the dominant strain. Based on this information, the isolation of $\mathrm{BLx}^{\mathrm{T}}$ on agar plates would have been expected, but was actually quite infrequent. The low rate of appearance on plates could be due to the reduced viability of $\mathrm{BLx}^{\mathrm{T}}$ in the samples collected and/or the inability of $\mathrm{BLx}^{\mathrm{T}}$ to compete effectively with other microorganisms for nutrients and/or inappropriate isolation conditions. The addition of an extract of decomposed matter was not effective in the isolation of $\mathrm{BLx}^{\mathrm{T}}$.

Strain $\mathrm{BLx}^{\mathrm{T}}$ is a motile Gram-positive rod, $0 \cdot 8 \times 2 \cdot 5$ $5.0 \mu \mathrm{m}$ in size. A spherical terminal endospore was found in the cell (Fig. 1). The colonies were pigmented (light yellowish-brown), round and opaque after 4 days incubation on TSA plates at $37^{\circ} \mathrm{C}$. Further incubation at $37^{\circ} \mathrm{C}$ or growth at $50^{\circ} \mathrm{C}$ on TSA resulted in the appearance of amorphous translucent colonies.

Sequence analysis of the $16 \mathrm{~S}$ rDNA was carried out with the PCR-amplified fragment (1484 bp). The sequence was aligned with 25 sequences of related species collected from the public databases. The alignment of $1331 \mathrm{bp}$ of each species' sequence was used for phylogenetic analysis. Phylogenetic tree analysis based on the neighbour-joining algorithm showed that strain $\mathrm{BLx}^{\mathrm{T}}$ belongs to Bacillus rRNA group 1 and is positioned within the cluster that includes the genera Virgibacillus (Arahal et al., 1999, 2000;

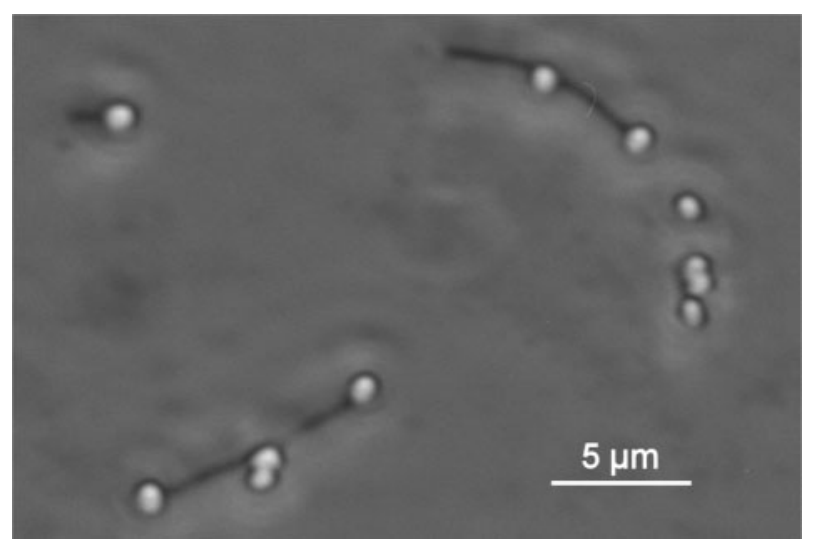

Fig. 1. Phase-contrast micrograph of cells of strain $B L x^{\top}$ after 12 days cultivation at $37^{\circ} \mathrm{C}$ on TSA supplemented with trace metal salts.
Heyndrickx et al., 1999; Heyrman et al., 2003; Garabito et al., 1997; Proom \& Knight, 1950; Wainø et al., 1999) and Lentibacillus (Yoon et al., 2002) (Fig. 2). The 16S rDNA sequence from strain $\mathrm{BLx}^{\mathrm{T}}$ showed $92 \cdot 8-94 \cdot 8 \%$ similarity to the genus Virgibacillus, $92.3 \%$ similarity to the genus Lentibacillus, and $92 \cdot 4-93 \cdot 5,92 \cdot 8$ and $92 \cdot 5-93 \cdot 1 \%$ similarity, respectively, to the genera Gracilibacillus (Lawson et al., 1996; Wainø et al., 1999), Paraliobacillus (Ishikawa et al., 2002) and Halobacillus (Spring et al., 1996). The highest similarity of $16 \mathrm{~S}$ rDNA to that of $\mathrm{BLx}^{\mathrm{T}}$ was that of Virgibacillus proomii $(94 \cdot 8 \%)$. However, B. licheniformis was originally identified as the closest relative. When the sequence of the DGGE band (variable region 3 of the $16 \mathrm{~S}$ $\mathrm{rDNA}$ ) of $\mathrm{BLx}^{\mathrm{T}}$ was compared with that of $B$. licheniformis and $V$. proomii, the levels of similarity were 96.3 and $94.4 \%$, respectively. The bootstrap resampling value (66\%) supported the positioning of strain $\mathrm{BLx}^{\mathrm{T}}$ in an independent lineage within the cluster that includes the genera Virgibacillus and Lentibacillus. The confidence level of the bootstrap analysis was $99 \%$ between this cluster and that comprising the genera Gracilibacillus, Paraliobacillus and Halobacillus. From the results of the phylogenetic analysis, $\mathrm{BLx}^{\mathrm{T}}$ was compared with members of the genera

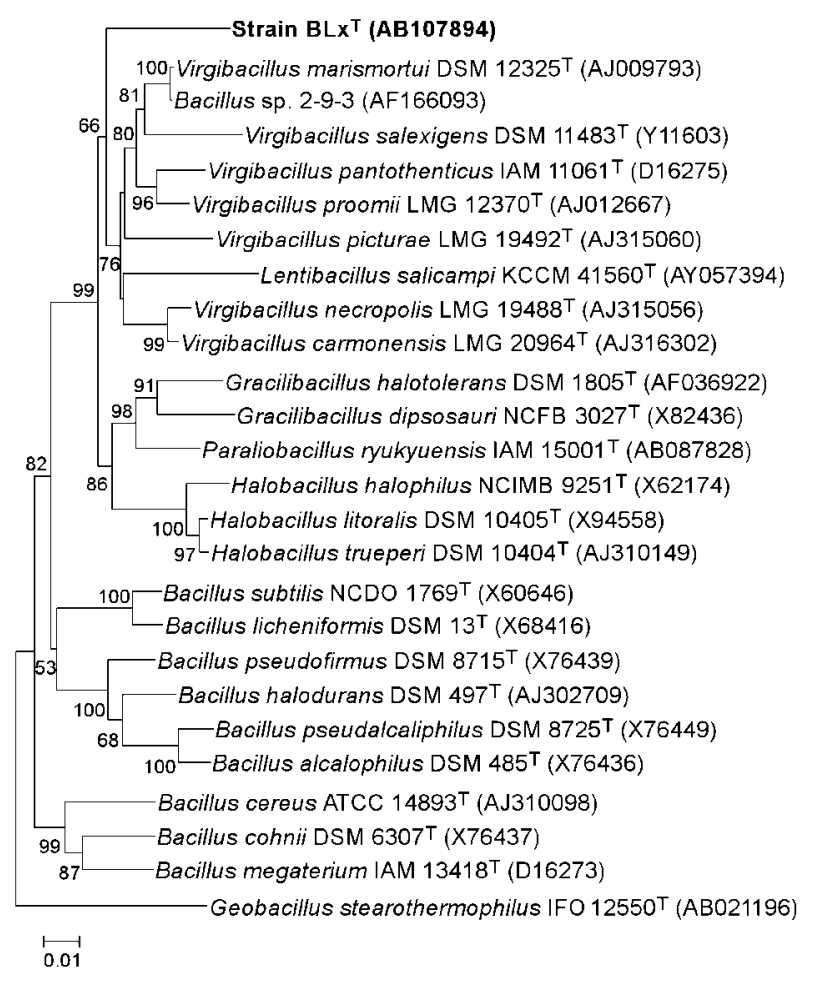

Fig. 2. Phylogenetic tree based on $16 \mathrm{~S}$ rDNA sequences of strain $\mathrm{BLx}^{\top}$ and related strains, constructed by neighbourjoining, with Geobacillus stearothermophilus as the outgroup. Numbers on the branches are bootstrap values (expressed as percentages) estimated by a bootstrap analysis performed with 1000 replicates. Bootstrap values less than $50 \%$ not shown. 
Table 1. Morphological, physiological and biochemical characteristics of strain BLx ${ }^{\top}$ and related taxa

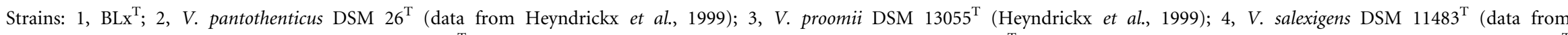

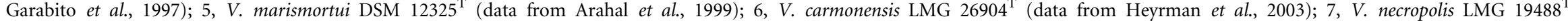

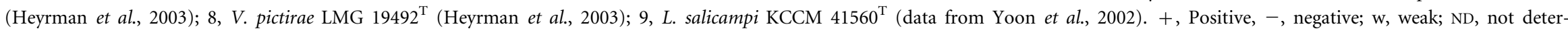
mined. Spore position: T, terminal; s, subterminal; C, central. Spore shape: E, ellipsoid; SP, spherical. None of the strains produce acid from lactose.

\begin{tabular}{|c|c|c|c|c|c|c|c|c|c|}
\hline Characteristic & 1 & 2 & 3 & 4 & 5 & 6 & 7 & 8 & 9 \\
\hline Morphology & $\begin{array}{l}\text { Rods, singly, } \\
\text { in pairs or in } \\
\text { short chains }\end{array}$ & $\begin{array}{l}\text { Rods, filaments, } \\
\text { singly or in chains }\end{array}$ & $\begin{array}{l}\text { Rods, filaments, } \\
\text { singly or in chains }\end{array}$ & $\begin{array}{l}\text { Rods, singly, } \\
\text { in pairs or in } \\
\text { short chains }\end{array}$ & $\begin{array}{l}\text { Rods, singly, } \\
\text { in pairs or in } \\
\text { short chains }\end{array}$ & $\begin{array}{l}\text { Rods, singly, } \\
\text { in pairs or in } \\
\text { short chains }\end{array}$ & $\begin{array}{l}\text { Rods, singly, } \\
\text { in pairs or in } \\
\text { short chains }\end{array}$ & $\begin{array}{l}\text { Rods, singly } \\
\text { or in pairs }\end{array}$ & Rods \\
\hline Colony pigmentation & $\begin{array}{c}\text { Light } \\
\text { yellowish-brown }\end{array}$ & Creamy-grey & Creamy-grey & None & Cream & Pink & None & None & Cream \\
\hline Spore position & $\mathrm{T}$ & $\mathrm{T}(\mathrm{s})$ & $\mathrm{T}(\mathrm{s})$ & $\mathrm{C}(\mathrm{s})$ & $\mathrm{T}(\mathrm{s})$ & $\mathrm{s}$ & $C(S, T)$ & $\mathrm{T}$ & $\mathrm{T}$ \\
\hline Spore shape & SP & E, SP & E, SP & $\mathrm{E}$ & $\mathrm{E}$ & E, SP & $\mathrm{E}$ & E, SP & SP \\
\hline Anaerobic growth & - & + & + & - & - & - & - & - & - \\
\hline \multicolumn{10}{|c|}{ Optimum conditions for growth: } \\
\hline Temperature $\left({ }^{\circ} \mathrm{C}\right)$ & 50 & 37 & 37 & 37 & 37 & $25-30$ & $25-35$ & $25-35$ & 30 \\
\hline $\mathrm{NaCl}$ concn $(\%)$ & $0 \cdot 5$ & 4 & ND & 10 & 10 & $5-10$ & $5-10$ & $5-10$ & $4-8$ \\
\hline Nitrate reduction & - & - & - & ND & + & + & + & + & ND \\
\hline $\mathrm{H}_{2} \mathrm{~S}$ production & - & $\mathrm{w}$ & - & + & + & - & - & - & $\mathrm{ND}$ \\
\hline \multicolumn{10}{|l|}{ Acid production from: } \\
\hline Glycerol & - & + & - & + & + & - & $\mathrm{w}$ & $\mathrm{w}$ & - \\
\hline D-Arabinose & - & + & - & - & - & - & - & - & - \\
\hline D-Ribose & + & + & + & ND & ND & - & $\mathrm{w}$ & - & - \\
\hline D-Xylose & + & - & - & - & - & - & - & - & - \\
\hline D-Fructose & - & + & + & + & + & - & $\mathrm{w}$ & $\mathrm{w}$ & - \\
\hline D-Galactose & - & + & + & - & - & - & - & $\mathrm{w}$ & - \\
\hline D-Glucose & - & + & + & + & + & - & $\mathrm{w}$ & $\mathrm{w}$ & - \\
\hline D-Mannose & - & + & + & + & ND & - & $\mathrm{w}$ & $\mathrm{w}$ & ND \\
\hline Maltose & - & + & + & + & + & - & - & $\mathrm{w}$ & - \\
\hline Sucrose & - & + & + & ND & - & - & - & - & ND \\
\hline D-Trehalose & - & + & + & - & - & - & $\mathrm{w}$ & - & - \\
\hline 5-Ketogluconate & + & - & - & ND & $\mathrm{ND}$ & $\mathrm{w}$ & $\mathrm{w}$ & - & ND \\
\hline \multicolumn{10}{|l|}{ Hydrolysis of: } \\
\hline Gelatin & + & + & $\mathrm{w}$ & + & + & - & $\mathrm{w}$ & - & ND \\
\hline Casein & - & + & + & + & + & + & + & + & + \\
\hline Starch & - & + & + & - & - & - & - & - & - \\
\hline Aesculin & - & + & + & + & + & $\mathrm{w}$ & - & - & - \\
\hline
\end{tabular}


Virgibacillus and Lentibacillus for the determination of its taxonomic position.

Strain $\mathrm{BLx}^{\mathrm{T}}$ could grow in TSB at temperatures between 30 and $55^{\circ} \mathrm{C}$ and at $\mathrm{pH} 7 \cdot 5-10$. Optimum growth was observed at $50^{\circ} \mathrm{C}$ and $\mathrm{pH} 8-9$. These conditions corresponded to those of the decomposed matter from which $\mathrm{BLx}^{\mathrm{T}}$ was isolated. Members of the genera Virgibacillus and Lentibacillus are mesophilic, so the optimum growth temperature discriminates $\mathrm{BLx}^{\mathrm{T}}$ from these genera. $\mathrm{BLx}^{\mathrm{T}}$ preferred a low $\mathrm{NaCl}$ concentration for growth: the maximum growth rate was observed at $0.5 \% \mathrm{NaCl}$ (standard concentration of $\mathrm{NaCl}$ in TSB). No growth was observed at $10 \% \mathrm{NaCl}$ in TSB. Growth of Virgibacillus species is stimulated by the addition of $\mathrm{NaCl}$, up to approximately $5 \%$. Lentibacillus salicampi grows optimally at $4-8 \% \mathrm{NaCl}$. From this phenotypic viewpoint, $\mathrm{BLx}^{\mathrm{T}}$ is quite different from these genera. Table 1 summarizes the morphological, physiological and biochemical characteristics of $\mathrm{BLx}^{\mathrm{T}} \mathrm{com}-$ pared to those of related taxa. BLx ${ }^{T}$ was capable of acid production from D-xylose, but could not hydrolyse casein. These biochemical properties also separate $\mathrm{BLx}^{\mathrm{T}}$ from members of the genera Virgibacillus and Lentibacillus.

The chemotaxonomic properties of strain $\mathrm{BLx}^{\mathrm{T}}$ were determined. The cell wall contained peptidoglycan of the mesoDAP type. The predominant quinone in the cell wall was unsaturated menaquinone with seven isoprene units (MK-7). The $\mathrm{G}+\mathrm{C}$ content of the genomic DNA was $35 \cdot 5 \mathrm{~mol} \%$. The chemotaxonomic properties of $\mathrm{BLx}^{\mathrm{T}}$ were compared with those of the related genera. All strains have mesoDAP as the diamino acid in the cell wall and MK-7 as the predominant quinone. In general, these properties are not appropriate criteria for the discrimination of genera within Bacillus rRNA group 1. However, the fatty acid profile was remarkably different (Table 2). BLx ${ }^{T}$ contained iso- $\mathrm{C}_{15: 0}$ as the major component $(67 \cdot 2 \%)$. Neither anteiso- $\mathrm{C}_{15: 0}$ nor anteiso- $\mathrm{C}_{17: 0}$ was detected. This composition of fatty acids discriminates $\mathrm{BLx}^{\mathrm{T}}$ from Virgibacillus species and Lentibacillus salicampi, which contain anteiso- $\mathrm{C}_{15: 0}$ or both anteiso- $\mathrm{C}_{15: 0}$ and iso- $\mathrm{C}_{15: 0}$ as the major component(s), and anteiso- $\mathrm{C}_{17: 0}$ as one of the minor components $(>10 \%)$. These results of phylogenetic, phenotypic and chemotaxonomic analyses support the classification of $\mathrm{BLx}^{\mathrm{T}}$ in a new genus, separated from the genera Virgibacillus and Lentibacillus. Therefore, we propose that $\mathrm{BLx}^{\mathrm{T}}$ is designated the type strain of a novel species in a novel genus, Cerasibacillus quisquiliarum gen. nov., sp. nov.

Cerasibacillus quisquiliarum strain $\mathrm{BLx}^{\mathrm{T}}$ was isolated from a semi-continuous decomposing system of kitchen refuse. The previous study indicated its abundance and its potential importance in garbage degradation. However, $\mathrm{BLx}^{\mathrm{T}}$ was detected in very low numbers on nutrient agar plates and had only a limited ability to assimilate carbohydrates and hydrolyse biopolymers (Table 1; species description). Further research will be necessary to understand the reason for its low recovery on agar plates and what role(s) $\mathrm{BLx}^{\mathrm{T}}$ plays during the decomposing process of kitchen refuse.
Table 2. Comparison of the cellular fatty acid profile of strain $\mathrm{BLx}^{\top}$ with those of related taxa

Cells were cultivated on MA at $30{ }^{\circ} \mathrm{C}$ for 7 days. Values represent percentage of each fatty acid, as measured by the MIDI system. Strains: 1 , Strain $\mathrm{BLx}^{\mathrm{T}} ; 2, V$. pantothenticus DSM $26^{\mathrm{T}} ; 3, V$. proomii DSM $13055^{\mathrm{T}} ; 4, V$. salexigens DSM $11483^{\mathrm{T}}$; 5, V. marismortui DSM $12325^{\mathrm{T}} ; 6$, Lentibacillus salicampi $\mathrm{KCCM} 41560^{\mathrm{T}}$. -, Not detected; tr, less than $1.0 \%$. Data from Yoon et al., 2002 for $V$. pantothenticus, $V$. proomii, $V$. salexigens (transferred from Salibacillus salexigens), V. marismortui (transferred from S. marismortui) and L. salicampi.

\begin{tabular}{|lcccccc|}
\hline Fatty acid & $\mathbf{1}$ & $\mathbf{2}$ & $\mathbf{3}$ & $\mathbf{4}$ & $\mathbf{5}$ & $\mathbf{6}$ \\
\hline iso-14:0 & $2 \cdot 4$ & $1 \cdot 4$ & $5 \cdot 2$ & $3 \cdot 0$ & $3 \cdot 5$ & $12 \cdot 0$ \\
iso-15:0 & $67 \cdot 2$ & $4 \cdot 9$ & $32 \cdot 2$ & $32 \cdot 9$ & $34 \cdot 4$ & $3 \cdot 4$ \\
anteiso-15:0 & - & $51 \cdot 7$ & $33 \cdot 1$ & $41 \cdot 7$ & $31 \cdot 4$ & $38 \cdot 6$ \\
$16: 1 \omega 7 c$ alcohol & $2 \cdot 6$ & - & - & $1 \cdot 5$ & $1 \cdot 0$ & $\operatorname{tr}$ \\
iso-16:0 & $2 \cdot 9$ & $6 \cdot 0$ & $7 \cdot 1$ & $4 \cdot 7$ & $7 \cdot 6$ & $30 \cdot 1$ \\
$16: 0$ & $10 \cdot 9$ & $1 \cdot 0$ & $\operatorname{tr}$ & $\operatorname{tr}$ & $1 \cdot 1$ & $1 \cdot 4$ \\
iso-17: $1 \omega 10 c$ & $3 \cdot 1$ & - & - & $\operatorname{tr}$ & - & - \\
iso-17:0 & $3 \cdot 2$ & $2 \cdot 4$ & $6 \cdot 5$ & $3 \cdot 5$ & $7 \cdot 6$ & $\operatorname{tr}$ \\
anteiso-17:0 & - & $31 \cdot 9$ & $10 \cdot 9$ & $10 \cdot 2$ & $10 \cdot 9$ & $13 \cdot 4$ \\
$18: 0$ & $7 \cdot 7$ & - & - & - & - & - \\
& & & & & & \\
\hline
\end{tabular}

\section{Description of Cerasibacillus gen. nov.}

Cerasibacillus (Ce.ras.i.ba.cil'lus. L. neut. n. cerasum a cherry; L. masc. n. bacillus small rod, N.L. masc. n. Cerasibacillus a cherry Bacillus, as the appearance of its sporangium is cherry-like).

Cells are Gram-positive rods, $0 \cdot 8 \times 2 \cdot 5-5 \cdot 0 \mu \mathrm{m}$ and motile and occur singly, in pairs or in short chains. Spherical endospores are produced terminally. Colonies are pigmented (light yellowish-brown), round and opaque at $37^{\circ} \mathrm{C}$ on TSA. Strictly aerobic. Good growth occurs at low concentrations of $\mathrm{NaCl}$. No growth within 6 days at $50{ }^{\circ} \mathrm{C}$ in TSB with $10 \% \mathrm{NaCl}$. Grows at $30-55^{\circ} \mathrm{C}$ (optimum $50^{\circ} \mathrm{C}$ ) and $\mathrm{pH} 7 \cdot 5-10$ (optimum $\mathrm{pH} 8-9$ ). Catalase and oxidase positive. Nitrate not reduced. Voges-Proskauer test and indole production negative. $\mathrm{G}+\mathrm{C}$ content $35 \cdot 5 \mathrm{~mol} \%$ (HPLC method). The cell wall contains peptidoglycan of the meso-DAP acid type. The major cellular fatty acid is iso- $\mathrm{C}_{15: 0}$ (cultured on MA at $30^{\circ} \mathrm{C}$ for 7 days). The main menaquinone type is MK-7. Acid produced from D-xylose. Casein not hydrolysed. The type species of the genus is Cerasibacillus quisquiliarum.

\section{Description of Cerasibacillus quisquiliarum sp. nov.}

Cerasibacillus quisquiliarum (quis.qui.li.a' rum. L. gen. pl. n. quisquiliarum of kitchen refuse).

Has the following properties in addition to those given in the genus description. Hydrolyses gelatin. No hydrolysis of starch, aesculin or urea. Acid produced from D-ribose, L-sorbose, D-tagatose and 5-ketogluconate. Acid is not 
produced from glycerol, erythritol, D-arabinose, L-arabinose, L-xylose, adonitol, methyl $\beta$-D-xylose, galactose, glucose, fructose, mannose, rhamnose, dulcitol, inositol, mannitol, sorbitol, methyl $\alpha$-D-mannose, methyl $\alpha$-D-glucose, $\mathrm{N}$-acetylglucosamine, amygdalin, arbutin, salicin, cellobiose, maltose, lactose, melibiose, sucrose, trehalose, inulin, raffinose, glycogen, xylitol, gentiobiose, D-turanose, D-fucose, L-fucose, D-arabitol, L-arabitol, gluconate or 2-ketogluconate.

The type strain, $\mathrm{BLx}^{\mathrm{T}}\left(\mathrm{DSM} 15825^{\mathrm{T}}=\mathrm{IAM} 15044^{\mathrm{T}}=\mathrm{KCTC}\right.$ $3815^{\mathrm{T}}$ ), was isolated from a semi-continuous decomposing system of kitchen refuse.

\section{Acknowledgements}

This research was supported by the Research for the Future Program of the Japan Society for the Promotion of Sciences (JSPS) and the JSPS Research Fellowships for Young Scientists. We appreciate Mr L. Ding for helping us to operate the decomposing system. We thank Professor Dr H. G. Trüper for advice on nomenclatural etymology.

\section{References}

Arahal, D. R., Márquez, M. C., Volcani, B. E., Schleifer, K. H. \& Ventosa, A. (1999). Bacillus marismortui sp. nov., a new moderately halophilic species from the Dead Sea. Int J Syst Bacteriol 49, 521-530.

Arahal, D. R., Márquez, M. C., Volcani, B. E., Schleifer, K. H. \& Ventosa, A. (2000). Reclassification of Bacillus marismortui as Salibacillus marismortui comb. nov. Int J Syst Evol Microbiol 50, 1501-1503.

Beffa, T., Blanc, M., Lyon, P. F., Vogt, G., Marchiani, M., Fischer, J. L. \& Aragno, M. (1996). Isolation of Thermus strains from hot composts (60 to 80 degrees C). Appl Environ Microbiol 62, 1723-1727.

Collins, M. D. \& Jones, D. (1982). A note on the separation of natural mixtures of bacterial menaquinones using reverse phase high performance liquid chromatography. J Appl Bacteriol 52, 457-460.

Dees, P. M. \& Ghiorse, W. C. (2001). Microbial diversity in hot synthetic compost as revealed by PCR-amplified rRNA sequences from cultivated isolates and extracted DNA. FEMS Microbiol Ecol 35, 207-216.

Devereux, R. \& Willis, S. G. (1995). Amplification of ribosomal RNA sequences. In Molecular Microbial Ecology Manual, vol. 3.3.1, pp. 1-11. Edited by A. D. L. Akkermans, J. D. van Elsas \& F. J. de Bruijn. London: Kluwer Academic Publishers.

Felsenstein, J. (1985). Confidence limits on phylogenies: an approach using the bootstrap. Evolution 39, 783-791.

Finstein, M. S. \& Morris, M. L. (1975). Microbiology of municipal solid waste composting. Adv Appl Microbiol 19, 113-151.

Fujio, Y. \& Kume, S. (1991). Isolation and identification of thermophilic bacteria from sewage sludge compost. J Ferment Bioeng 72, 334-337.

Garabito, M. J., Arahal, D. R., Mellado, E., Márquez, M. C. \& Ventosa, A. (1997). Bacillus salexigens sp. nov., a new moderately halophilic Bacillus species. Int J Syst Bacteriol 47, 735-741.

Haruta, S., Kondo, M., Nakamura, K., Aiba, H., Ueno, S., Ishii, M. \& Igarashi, Y. (2002). Microbial community changes during organic solid waste treatment analyzed by double gradient-denaturing gradient gel electrophoresis and fluorescence in situ hybridization. Appl Microbiol Biotechnol 60, 224-231.
Heyndrickx, M., Lebbe, L., Kersters, K., Hoste, B., De Wachter, R., De Vos, P., Forsyth, G. \& Logan, N. A. (1999). Proposal of Virgibacillus proomii sp. nov. and emended description of Virgibacillus pantothenticus (Proom and Knight 1950) Heyndrickx et al. 1998. Int J Syst Bacteriol 49, 1083-1090.

Heyrman, J., Logan, N. A., Busse, H. J., Balcaen, A., Lebbe, L., Rodriguez-Diaz, M., Swings, J. \& De Vos, P. (2003). Virgibacillus carmonensis sp. nov., Virgibacillus necropolis sp. nov. and Virgibacillus picturae sp. nov., three novel species isolated from deteriorated mural paintings, transfer of the species of the genus Salibacillus to Virgibacillus, as Virgibacillus marismortui comb. nov. and Virgibacillus salexigens comb. nov., and emended description of the genus Virgibacillus. Int J Syst Evol Microbiol 53, 501-511.

Ishii, K., Fukui, M. \& Takii, S. (2000). Microbial succession during a composting process as evaluated by denaturing gradient gel electrophoresis analysis. J Appl Microbiol 89, 768-777.

Ishikawa, M., Ishizaki, S., Yamamoto, Y. \& Yamasato, K. (2002). Paraliobacillus ryukyuensis gen. nov., sp. nov., a new Gram-positive, slightly halophilic, extremely halotolerant, facultative anaerobe isolated from a decomposing marine alga. J Gen Appl Microbiol 48, 269-279.

Kimura, M. (1980). A simple method for estimating evolutionary rates of base substitutions through comparative studies of nucleotide sequences. J Mol Evol 16, 111-120.

Kumar, S., Tamura, K., Jakobsen, I. B. \& Nei, M. (2001). MEGA2: molecular evolutionary genetics analysis software. Bioinformatics $\mathbf{1 7}$, 1244-1245.

Kurisu, F., Satoh, H., Mino, T. \& Matsuo, T. (2002). Microbial community analysis of thermophilic contact oxidation process by using ribosomal RNA approaches and the quinone profile method. Water Res 36, 429-438.

LaMontagne, M. G., Michel, F. C., Holden, P. A., Jr \& Reddy, C. A. (2002). Evaluation of extraction and purification methods for obtaining PCR-amplifiable DNA from compost for microbial community analysis. J Microbiol Methods 49, 255-264.

Lawson, P. A., Deutch, C. E. \& Collins, M. D. (1996). Phylogenetic characterization of a novel salt-tolerant Bacillus species: description of Bacillus disposauri sp. nov. J Appl Bacteriol 81, 109-112.

Nakasaki, K., Shoda, M. \& Kubota, H. (1985). Effect of temperature on composting of sewage sludge. Appl Environ Microbiol 50, 1526-1530.

Pedro, M. S., Haruta, S., Nakamura, K., Hazaka, M., Ishii, M. \& Igarashi, Y. (2003). Isolation and characterization of predominant microorganisms during decomposition of waste materials in a fieldscale composter. J Biosci Bioeng 95, 368-373.

Peters, S., Koschinsky, S., Schwieger, F. \& Tebbe, C. C. (2000). Succession of microbial communities during hot composting as detected by PCR-single-strand-conformation polymorphism-based genetic profiles of small-subunit rRNA genes. Appl Environ Microbiol 66, 930-936.

Proom, H. \& Knight, B. C. J. G. (1950). Bacillus pantothenticus (n. sp.). J Gen Microbiol 4, 539-541.

Ryckeboer, J., Mergaert, J., Coosemans, J., Deprins, K. \& Swings, J. (2003). Microbiological aspects of biowaste during composting in a monitored compost bin. J Appl Microbiol 94, 127-137.

Saitou, N. \& Nei, M. (1987). The neighbor-joining method: a new method for reconstructing phylogenetic trees. Mol Biol Evol 4, 406-425.

Schleifer, K. H. (1985). Analysis of the chemical composition and primary structure of mulein. Methods Microbiol 18, 123-156.

Spring, S., Ludwig, W., Marquez, M. C., Ventosa, A. \& Schleifer, K. H. (1996). Halobacillus gen. nov., with descriptions of Halobacillus litoralis sp. nov., and Halobacillus trueperi sp. nov., and transfer of Sporosarcina halophila to Halobacillus halophilus comb. nov. Int J Syst Bacteriol 46, 492-496. 
Strom, P. F. (1985a). Effect of temperature on bacterial species diversity in thermophilic solid-waste composting. Appl Environ Microbiol 50, 899-905.

Strom, P. F. (1985b). Identification of thermophilic bacteria in solid-waste composting. Appl Environ Microbiol 50, 906-913.

Tamaoka, J. \& Komagata, K. (1984). Determination of DNA-base composition by reversed-phase high-performance liquid chromatography. FEMS Microbiol Lett 25, 125-128.

Thompson, J. D., Gibson, T. J., Plewniak, F., Jeanmougin, F. \& Higgins, D. G. (1997). The CLUSTAL_X windows interface: flexible strategies for multiple sequence alignment aided by quality analysis tools. Nucleic Acids Res 25, 4876-4882.

Wainø, M., Tindall, B. J., Schumann, P. \& Ingvorsen, K. (1999). Gracilibacillus gen. nov., with description of Gracilibacillus halotolerans gen. nov., sp. nov.; transfer of Bacillus dipsosauri to Gracilibacillus dipsosauri comb. nov., and Bacillus salexigens to the genus Salibacillus gen. nov., as Salibacillus salexigens comb. nov. Int J Syst Bacteriol 49, 821-831.

Watanabe, K., Kodama, Y. \& Harayama, S. (2001). Design and evaluation of PCR primers to amplify bacterial $16 \mathrm{~S}$ ribosomal DNA fragments used for community fingerprinting. J Microbiol Methods 44, 253-262.

Yoon, J. H., Kang, K. H. \& Park, Y. H. (2002). Lentibacillus salicampi gen. nov., sp. nov., a moderately halophilic bacterium isolated from a salt field in Korea. Int J Syst Evol Microbiol 52, 2043-2048.

Zhu, H., Qu, F. \& Zhu, L. H. (1993). Isolation of genomic DNAs from plants, fungi and bacteria using benzyl chloride. Nucleic Acids Res 21, 5279-5280. 